\title{
FOUNDATION DEVELOPMENT FROM 1890-1942 FOR LONG SPAN AND HIGH RISE BUILDINGS AT MÉXICO CITY
}

\author{
PERLA SANTA ANA ${ }^{1 *}$, LUCIA SANTA ANA ${ }^{1}$ AND JOSE I. BAEZ ${ }^{2}$ \\ ${ }^{1}$ Laboratorio de Materiales y Sistemas Estructurales, \\ Facultad de Arquitectura \\ Universidad Nacional Autónoma de México, CDMX, México

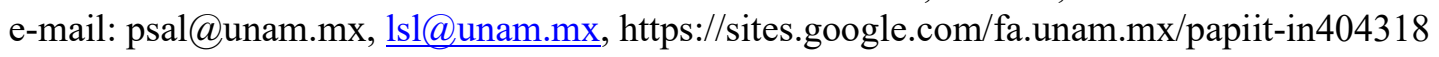 \\ ${ }^{2}$ Baez Santa Ana Ingenieros Consultores, \\ Research Area, CDMX, México \\ email: jibg@bsiconsultores.com
}

Keywords: Historical Structure, Foundations, High Rise Buildings, Development

\begin{abstract}
The subsoil of Mexico City, Mexico, has had a complex behavior; filled with light flocculent structure and layers at different depths of stiff material, producing regional and local differential settlements and liquefaction being a seismic zone. Long Span and High Rise buildings in this City have been a challenge to construct, being its foundation solution, one of the essential elements for its success. This study aims to present the evolution of the long span and skyscraper in Mexico City, being the foundation solution a crucial issue for this new construction era. The foundation solution of five iconic buildings built during this period analyzed by their designers and authors of this paper is presented. Each foundation solution is evaluated considering today's advance in Mexican soil mechanics, arriving at the solution most used nowadays in the city for this kind of buildings.
\end{abstract}

\section{INTRODUCTION}

Since early times the subsoil of Mexico City has been a challenge for engineers and architects to erect buildings without suffering settlements because of its stratified soil sediments of high and very high compressibility in addition to strong earthquakes and ground surface subsidence. The characterization of Mexico City subsoil started in 1948 with Engineer Nabor Carillo [1] and continue with Leonardo Zeevaert in 1952 [2] and Marsal and Mazari in 1959 [3] continuing this task until nowadays. Its complex behavior is due to its stratigraphical and hydrological conditions.

\section{GEOTECHNICAL PROPERTIES OF THE VALLEY}

The Valley of Mexico City is formed by volcanic and pyroclastic materials, interspersed with alluvial deposits covered with lacustrine clays. The valley remained a closed basin with several shallow lakes (like Texcoco, Chalco, Xochimilco, among others), and it became an open basin in 1789 . The lakes were drained during the $20^{\text {th }}$ Century, leaving the valley with lacustrine sediments. These are highly plastic soft clays interbedded with layers of silt, sand, 
and sandy gravels of alluvial origin. [4]. According to Marsal and Mazari [3], there is at the top a desiccated crust of artificial fill, underneath are the upper and lower clay layer separated between by a hard layer and a sandy, clayey stratum. The composition of this volcanic clay is a mixture of a) clayey and non-clayey minerals with microorganisms, b) dissolved salts and, c) organic components (i.e., ostracodes and diatoms). [5].

This soft lacustrine soil has been suffering a consolidation process due to the exploitation of the aquifers underlying the old lake zones. [5]. Because of its composition and drainage, the subsoil of this Valley has a subsidence today around 30 to $40 \mathrm{~cm}$ per year, and the sinking process of the city will continue producing differential settlements on the foundations, especially from the iconic heritage buildings. Earthquake of 1985 shows that this soft soil on the surface settled after the tremor being interpreted this behavior as an instantaneous vertical displacement induced by the residual expansion as the seismic waves travel through the soil mass. [6]. The upper layer clay is highly plastic, remaining elastic with low damping, explaining that for large-amplitude cyclic strains, the clay structure degrades continuously, causing pore water pressure variations and reductions in stiffness and strength. [5].

\section{FOUNDATION DEVELOPMENT AT THE CITY VALLEY}

Around 1840 first general studies of the subsoil were made to get an unconfined compressive strength that avoids or diminishes structural settlements. Militar engineer Gonzalo Garita worked hypothesis from the practical engineering point of view and, as a result, established a value of $\mathbf{5}$ ton/m2 as bearing capacity of the substrate [7] and started using slab foundation concrete slab to distribute the

3.1 Casa Boker, 1898

The main objective of the Porfirio Diaz government was to build iconic buildings showing

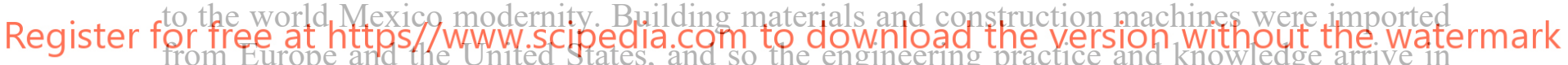
Mexico too.

Living Mexico City in this modernity, Family Boker introduced to the country the new way of shopping and decided to open a department store downtown. This building was constructed by architects De Lemos y Cordes with the participation of the engineer Gonzalo Garita. It was one of the first steel department store buildings built in Mexico City with four stories high (higher than all the buildings around). The structural design, building system, and must materials (steel and concrete) were imported mainly from the United States, as the contractor hired for this job was Milliken Brothers Company around 1980, with their main offices in New York.

The spans for this new building were $5.5 \mathrm{~m}$ in both directions, with a floor height of $4 \mathrm{~m}$. As this store was a replicate from the ones being constructed in New York, selling any engine, car, or electro domestic furniture, the live load used for its structural design was $119 \mathrm{MPa}$ as it was considered as a warehouse. [7]. The structural system used for this building by Milliken Brothers was the "Skeleton Construction Plan" (a semirigid steel frame with " $Z$ bars" columns and standard I beams). Floors were fireproof constructed with a steel rolled plate supported by secondary beams and filled the upper part with concrete. 
The foundation solution used was the "continuous grillage foundation"; it consists of twolayer steel beam grillage embedded in concrete with a bed thickness of 1.96 meters and covering an area of $1700 \mathrm{~m}^{2}$ ( $3 / 4$ of the total building area). The main steel beams for this grillage had a section designated "IE" with a depth between 45 and $50 \mathrm{~cm}$., while the second line was steel beams of $20 \mathrm{~cm}$ depth. This kind of foundation solution was used around 1905 in Chicago and New York tall buildings; the only difference was that rails of cast iron were used instead of steel. [13].

Analyzing today the weight of the building, considering live loads (63 MN) and the weight of the foundation ( $76 \mathrm{MN}$ ), it can be observed that the foundation system weights $20 \%$ more than the building's load. The weight of the foundation and structure was of $68.64 \mathrm{KPa}$, slightly higher than the $49 \mathrm{KPa}$ bearing capacity established for that site. Fortunately, the building never had the live load considered in its structural design, reaching the $49 \mathrm{KPa}$ of soil bearing capacity. This building still stands today, and it continues to be a store with offices in its upper levels, and it has only a small differential settlement of around $5 \mathrm{~cm}$ over one corner, concluding that this kind of foundation could be used for buildings of 3 to 4 levels) over soft soil.

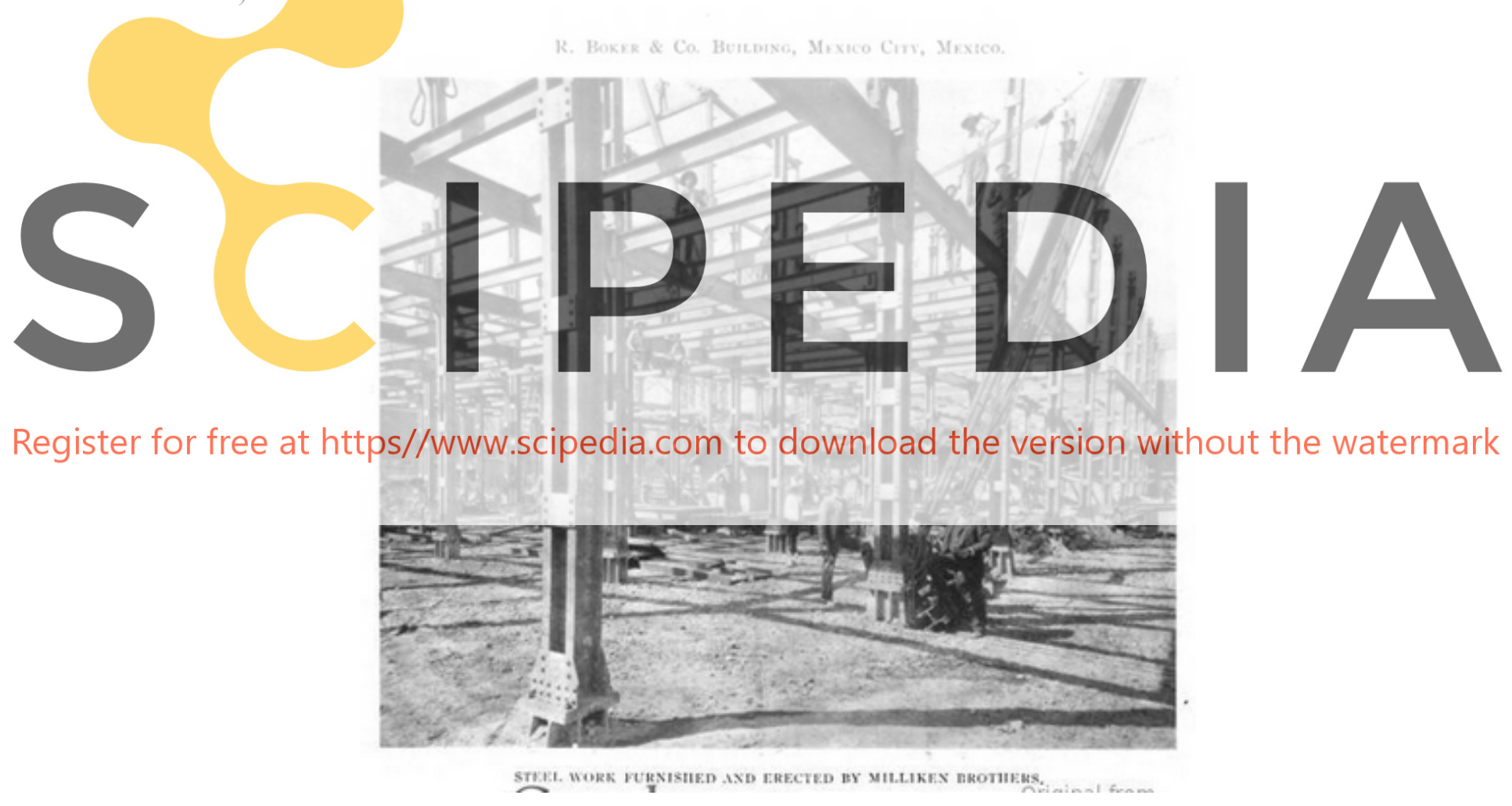

Figure 1: Casa Boker Construction, from Milliken Brothers Catalogue 1903.

\subsection{Palacio de Bellas Artes, 1904}

This iconic building design by architect Adamos Boari and structural design by W. Birkmire started its construction in 1904 and ended until 1934. This building is four stories high with a structural system of steel frames for all its stories. Perimeter non-bearing walls are 
of concrete wrapped with marble plaques; they make the façade of the building. In its interior, spans are variable; the small spacing between columns is $5 \mathrm{~m}$, and the longest is around $25 \mathrm{~m}$ located inside the main theater. Concrete and most of the steel structure was imported from the United States, only the steel for its foundation was produced in Mexico.

The foundation selected for this massive building was continuos grillage, made with two layers of beam grillage embedded in concrete. It was considered an underground basement of two meters for all the building except under the theater stage, which was three meters depth. During the excavation process, they found pre-hispanic ruins (consolidating clays where the ruins were) underneath the substrata, so they decided to increase the basement depth only 50 cm more. [14]

This steel building has an extraordinary deadweight (floors and walls were covered with marble, spans were $13 \mathrm{~m}$ long, more significant than any other edifice constructed by that time). Engineer Birkmire decided to use as main steel beams for the grillage sections "IE" type of $60 \mathrm{~cm}$ depth. This steel section was used for making the two layers grillage embedded in a concrete slab of $2.32 \mathrm{~m}$ of thickness. The total weight of the foundation was $381 \mathrm{MN}$, while the building weight was $395 \mathrm{MN}$, making a total weight of $778 \mathrm{MN}$. Considering today the basement as a floating raft foundation, the total weight of the building that received the substrata was $72 \mathrm{KPa}$, higher than the $51 \mathrm{KPa}$ substrata capacity [8]. Differential settlement problems started since the beginning of the construction and, along with the construction progress, stopping it several times; the problem was not the weight of the building, while it was only the steel skeleton erected.

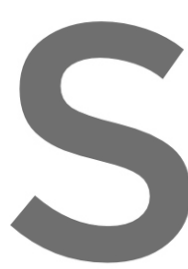

When the settlement flashboards around the water. Still, the settlem
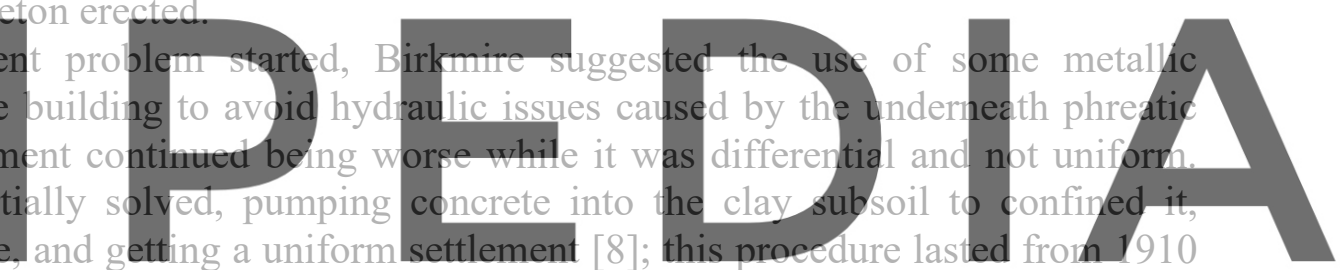
to 1925. Analyzing today the foundation of this building, it can be concluded that the pre-

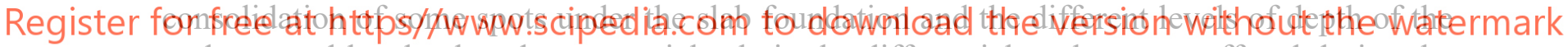
underground levels played an essential role in the differential settlements suffered during the building progress. Today this building is $2.33 \mathrm{~m}$ below its original construction level, being subsidence the leading cause of this effect. 


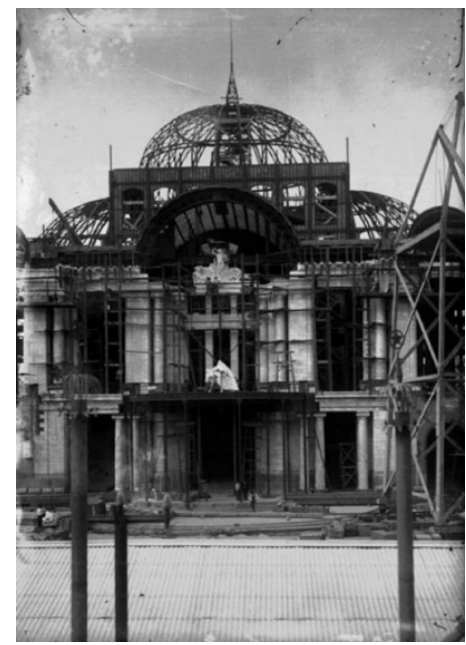

Figure 2: Construction of Palacio Bellas Artes, from Milliken Brothers Catalogue 1912.

\subsection{La Nacional Building, 1930}

Since 1908, Mexican engineers did not consider the grillage foundation as an adequate solution for soft clay soils like the one in Mexico City. Hence, engineers of that time decided to use wood point bearing piles supported in the bearing stratum as a better foundation solution, using it for the column of independence built in Mexico City in 1900 and inaugurated in 1910 by Porfirio Diaz,
With the growth of Mexico City, there w
authorities created and published in 1920 the
regulations about architecture solutions and
process. Because must of the times buildings
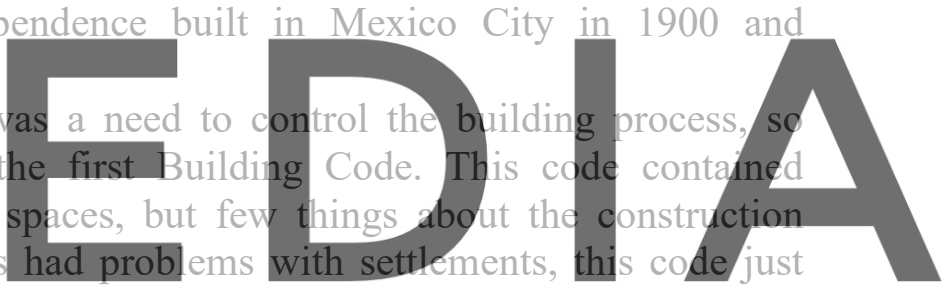

stated the bearing capacity of the soil as $49 \mathrm{KPa}$ and must housing buildings should have a

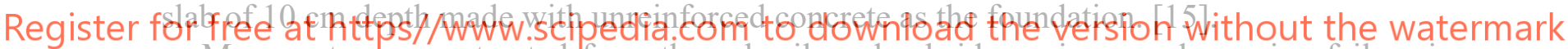

More water was extracted from the subsoil, and subsidence increased, causing failure in the city drainage system and soil surface cracking all over the city. In 1925, Roberto Gayol was the first engineer to study the properties of the subsoil from Mexico City while building the main drainage of the city.

The life insurance company called La Nacional, Compañía de Seguros para la Vida SA, (founded by W. Woodrow and L. Neergard) hired in 1901 the architects Monasterio and Calderón to design a building for their company. They proposed a 13 story building with 55 $\mathrm{m}$ height; it was the first skyscraper of Mexico City. The primary structural system is steel frames with reinforced concrete floors; all the steel structure was protected with reinforced concrete to make it fire resistant and giving a higher strength to the structural system without knowing. Because the Building code of 1920 did not include any section about structural design, engineers used the American 1923 AISC allowable stress design. Spans are regular of $7 \mathrm{~m}$ in both directions; floors support the facades which are made with non-bearing concrete walls.

The building has a total weight of $89 \mathrm{MN}$ with a built surface of $735 \mathrm{~m} 2$, generating a unit pressure to the substrate in case of using a slab foundation of $142 \mathrm{KPa}$, which is a higher pressure than the substrata capacity established by the building code $(49 \mathrm{KPa})$. Soil tests were 
performed and analyzed; standard penetration tests were made, and the soil profiles were analyzed, finding sand with a small amount of lime and clay stratum with the thickness and resistance required for supporting piles. The depth of this resistant stratum was $36 \mathrm{~m}$ from the surface [9].

With Dr. Karl Terzaghi working as a consultant, the foundation solution assigned for this building was a two-level box type and wood point bearing piles below the box. Because floating foundations were not known by that time, it was ignored the compensation effect of the box, and all the weight was considered to be supported by the woodpiles. A total of 373 piles of $30 \mathrm{~cm}$ diameter were used; piles were segmented in sections of 6 to $8 \mathrm{~m}$ long. The piles were fitted with cast iron points and caps to prevent damage to its bottom during the phase of operation; they were joined together in their upper part with the beams that support the concrete slab of the box. [9].

Not all the piles reached the hard stratum, but considering the compensation work of the basement box, the piles that reached the stratum were enough to support the building. After a series of 4 strong earthquakes and changes in live loads, this building remains until today open and functioning. It has a differential settlement of $7 \mathrm{~cm}$ over a corner, and it has emerged approximately $50 \mathrm{~cm}$. This settlement produced where the piles did not reach the hard stratum; also, this stratum could have suffered changes, while the other four buildings nearby (Torre Latinoamericana among them) also stands over it.
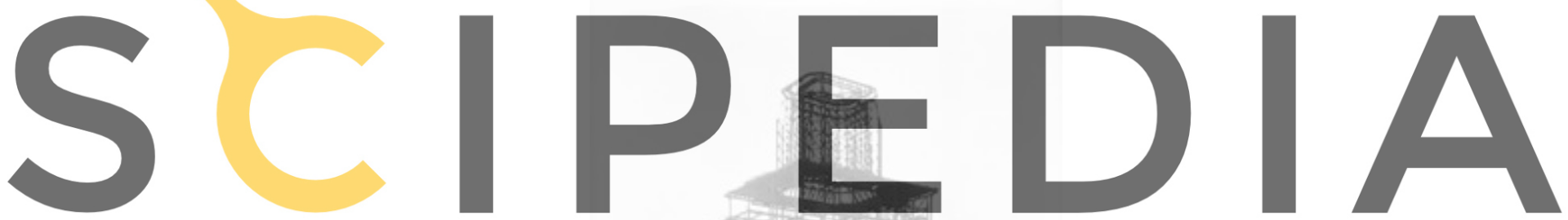

Register for free at https//www.scipedia.com to download the version without the watermark

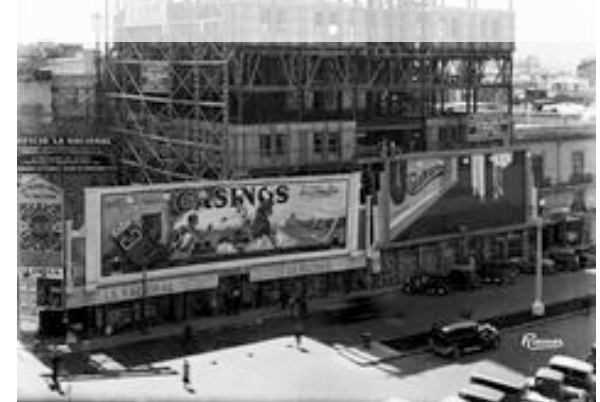

Figure 4: La Nacional Building, courtesy of Archive Fundacion Ramos.

\subsection{Loteria Nacional Building, 1933}

In 1933 the National Lottery system hired architect Ortiz Monasterio and engineer José Antonio Cuevas to built its new house. With an irregular shape and three sections, this building is $66 \mathrm{~m}$ tall, with 20 stories in the central tower. Its structural system consists of 
steel frames using beams and trusses because of the spans at the auditorium $(15 \mathrm{~m}$ long approximately and a height of $18 \mathrm{~m}$ ). Columns are protected with reinforced concrete, and floors are reinforced concrete slabs. This building is one of the first skyscraper built with Mexican materials (concrete and steel).

The foundation solution design and built for this building was a floating foundation; this was the first time this foundation solution is used in Mexico City. The global solution consisted of a two-level concrete box of $10 \mathrm{~m}$ depth, stiffened with concrete trusses; the soil is in general composed of clay stratum with a high phreatic level creating heave as the soil was removed.

Before beginning the construction, engineer Cuevas started analyzing the mechanic properties of the soil. He evaluated the soil's density, which changed as ít came from a deeper layer; the variation of its specific weight was from $12.6 \mathrm{kN} / \mathrm{m}^{3}$ at the top to $10 \mathrm{kN} / \mathrm{m}^{3}$, at 1.8 $\mathrm{m}$ depth. The phreatic level was found at $-1.80 \mathrm{~m}$., so the soil under this level could reach a density of $28.5 \mathrm{kN} / \mathrm{m} 3$. Phreatic water was pumped out of the field to maintained dry the construction site.

Because there were no soil mechanic laboratories, engineers could not know the soil elastic and plastic reaction; Cuevas started measuring deformations every day, discovering that the subsoil swells $1.27 \mathrm{~m}$ in eight months. He lay a flexible wood with a waterproof membrane over it; concrete " $\mathrm{T}$ " inverted beams were constructed, and additional weight was placed like ballast in order to push the subsoil to its original level. The ballast was removed as the construction developed, and the weight of the box foundation restrain the soil to its original position and the loads trat

As the building was

concrete box below the a

the basement of the niain
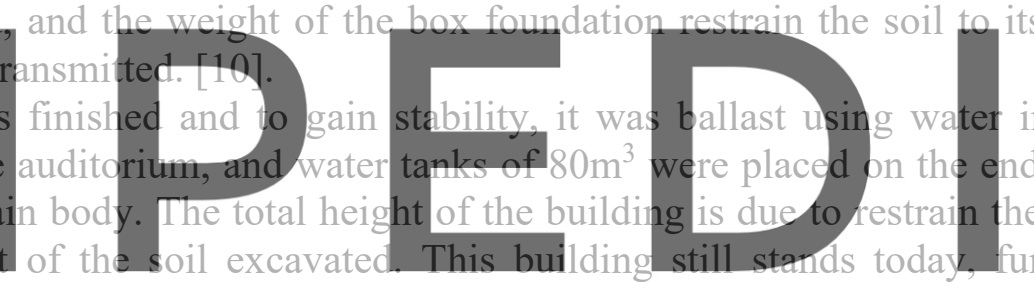

normally; earthquakes have cause minor affectations, and differential settlements $(19 \mathrm{~cm}$ at

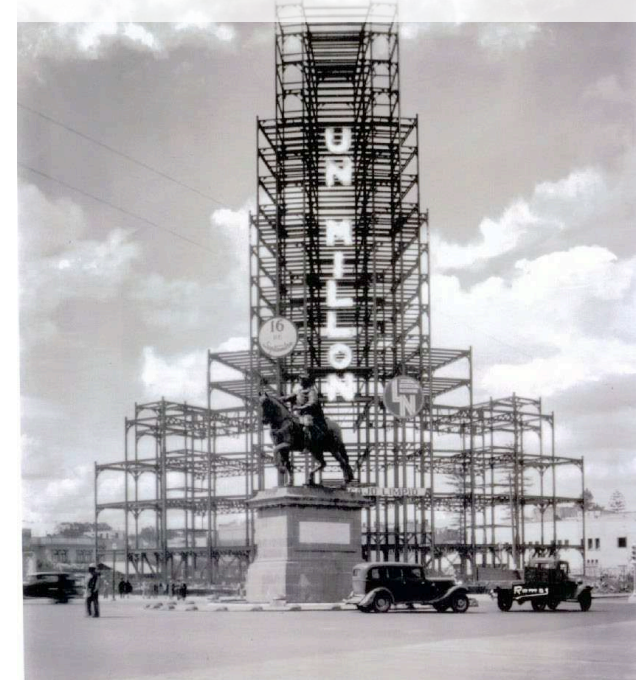

Figure 5: La Loteria Nacional, courtesy of Archive Fundacion Ramos 


\subsection{Introduction in Mexico City to soil mechanics and seismic effects}

In 1941 an earthquake stroke Mexico City; buildings from 10 to 18 stories constructed over soft soil suffered structural damages. This earthquake forced authorities to review the building code and invited engineers to research soil properties and seismic actions.

In 1942 the new building code for Mexico City was published; this is the first code to established a substrata capacity equal to $49 \mathrm{kPa}$ when the soil was pre-consolidated or 29.4 $\mathrm{kPa}$ if it has never been used for construction. The most popular foundation solutions were concrete slabs and isolated concrete footings; the use of grillage using reinforced concrete and iron or steel sections remained. When tall or heavy buildings were built, it was allowed to use bearing piles supported on rigid stratum; piles could be made of concrete or wood. [16].

Between 1946 to 1956, engineer Nabor Carrillo began the scientific study of soils (soil mechanics), especially of clays and soft soils. He specialized in the behavior of foundations supported by different types of soil, stablishing that difficult foundation problems were found in very fine water laid sediments of high compressibility stratified with sand layers, exhibiting high secondary compression (or intergranular viscosity, as he named it) as these silty clays or clayeye silts have high viscous behaviour induced by the relative displacement of the mineral grains. [11].

\subsection{Torre Latinoamericana, 1948}

The insurance company Latinoamericana Seguros gave the commission to architect Agusto
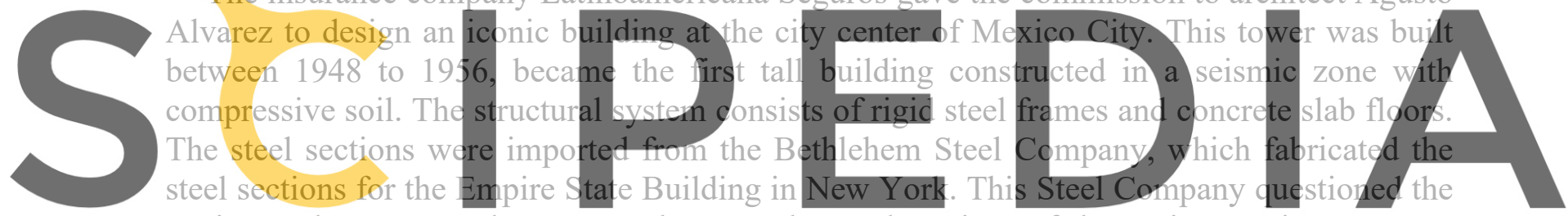

engineer Ph.D. Leonardo Zeevaert because the steel sections of the Latinoamericana Tower

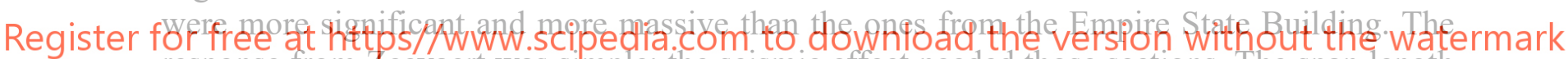
response from Zeevaert was simple; the seismic effect needed those sections. The span length is constant of $7 \mathrm{~m}$ in each direction.

Zeevaert was in charge of the foundation and structural design. He studied the structural system and foundation solution in order to get a safe building. The architectural design followed the recommendation of the engineer in order to obtain an excellent seismic and foundation behavior, some of the action taken was: light partition walls, regular geometry of the building, number of stories. The foundation and soil behavior was considered when the seismic design for this building was evaluated. [17].

The subsoil conditions were investigated, with the following results: the first $5.55 \mathrm{~m}$ a fill was found of clayey silt, sand with humues and Aztec pottery remain; the content of water was $45 \%$. The following $20 \mathrm{~cm}$ a layer with black volcanic ash with silt and clay was found. The next $2 \mathrm{~m}$ were formed with light grey silty clay with high content of calcium carbonates and a water content of $100 \%$ and pumice sand. The last layers were lacustrine volcanic clay with brown pumice sand. [12].

The foundation solution was a floating raft with a concrete box, with a unit load at the foundation of $206.9 \mathrm{kPa}$. The reinforced concrete mat foundation is located at a depth of 13 $\mathrm{m}$, and it is $60 \mathrm{~cm}$ thick; in order to ensure no settlements, 361 concrete point piles were built 
under the reinforced concrete mat. Piles were driven to a depth of $33.5 \mathrm{~m}$ into a firm sand layer acting as point bearing piles; this layer was selected to avoid large negative friction on the piles. Both elements (box and piles) were designed to stand the total weight of the building separately. Piles were Button Bottom with $30 \mathrm{~cm}$ of diameter; they were poured in the site, and the concrete compression stress was equal to $73.54 \mathrm{MPa}$, having a prefabricated concrete point of $43 \mathrm{~cm}$ diameter.
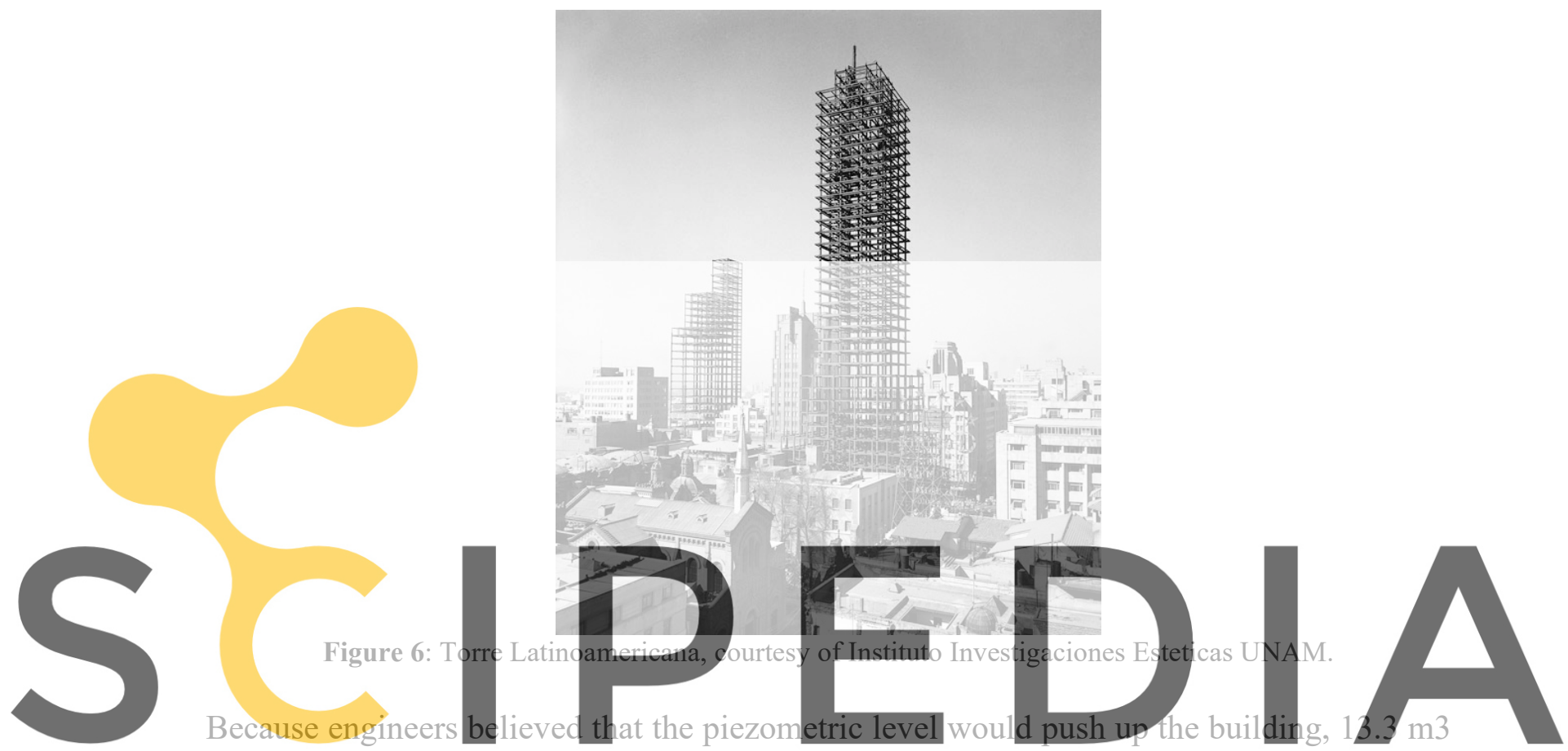

per day of water was pumped to the soil in order to assure flotation. This special hydraulic

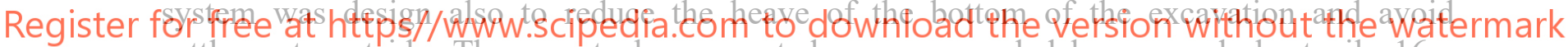
settlements outside. The area to be excavated was surrounded by a wood sheet pile $16 \mathrm{~m}$ depth; upon saturation this membrane did not allowed the entrance of water in the excavation; the pressure in the sand layers was maintained by injecting clean water under pressure in the subsoil using eight wells all over the building surface. The heave was avoided by producing a strong reduction in the piezometric water levels inside the wood sheet-pile to keep the same effective pressures. In order to take care of ground surface subsidence, the ground floor was was divided into panels supported on wood blocks, permitting the panels to be lowered as required. [12].

This building has emerged approximately $100 \mathrm{~cm}$ as predicted by Dr. Zeevaert; it has survived the most significant earthquakes of Mexico City, and it stands without any damage or settlement.

\section{CONCLUSIONS}

It is essential to learn about the success and failure of foundation solutions applied for compressible clay soil like the one in Mexico City. The buildings that are designed and constructed today, taller, with irregular shapes and greater span lengths, are a product of the advances in technology but mainly in the research of soil properties and behavior of 
foundations over different kinds of soils.

Acknowledgments. Authors acknowledge all researchers that have made possible the development of soil mechanics in Mexico City. This work was supported by UNAM-PAPIIT IN404318.

\section{REFERENCES}

[1] Carrillo N. Influence of artesian wells in the sinking of Mexico City. Second International Conference on Soil Mechanics and Foundation Engineering. Rotterdam, Nederland (1948)

[2] Zeevaert L. Estratigrafía y Problemas de la ingeniería de los depósitos de arcilla lacustre de la ciudad de México. Scientific Congress of the Fourth Centenary of the National University of Mexico, Proceedings, Mexico (1952) 30: 155-176

[3] Marsal R. and Mazari M. The Subsoil of Mexico City. Contribution to First PanAmerican Conf. on Soil Mechanics and Found. Engineering, Facultad de Ingeniería, UNAM, Mexico (1959)

[4] Marsal R. and Mazari M. The Subsoil of Mexico City. Contribution to First PanAmerican Conf. on Soil Mechanics and Found. Engineering, Facultad de Ingeniería, UNAM, Mexico (1959)

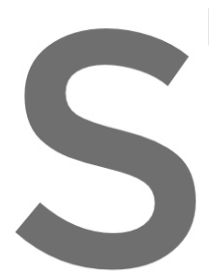

[5] Auvinet G. y Juare Am Geotechnical C

[6] Zeevaert-Wiechers motivado por el 49-54.

[7] Katzman I. La Arquit Moises. Geotechnical characterizatio
Conference, (2011)
L. Análisis y pronóstico del hundim
ismo. (Eds.): Ingeniería Investigación
uitectura Contemporánea Mexicana: P ion of Mexico City Subsoil. Pan
miento de la superficie del suelo
Predecentes y Desarmollo. NAH, Mexico,(1993) pg 125-130

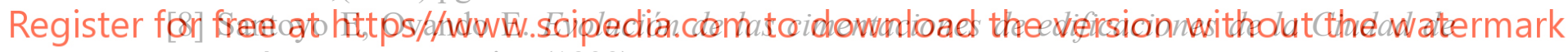
México. TGC, Mexico,(1999)

[9] Ortiz M Cimentación de pilotes en la Ciudad de México. (Eds.): Arquitectura y decoración, 19, (1937), pp. 22-26.

[10] Martinez R, Tamez E. Revisión geotécnica de la cimentación del edificio de la Loteria Nacional. TGC, Mexico,(1986)

[11] Santoyo E. Sintesis Geotécnica de la Cuenca del Valle de México TGC, Mexico,(2005)

[12] Zeevaert-Wiechers L. Foundation Design and Behavior of Tower Latino Americana in Mexico City. Geotechnique, (1957), vol.7.

[13] Böker, R. Historia de la Casa Boker. Casa Böker, Mexico,(2019)

[14] Birkmire,W Contrato con Ing. Birkmire para la cimentación del Teatro Nacional. Archivo General de la Nación, Fondo COP (1905)

[15] Gobierno Constitucional de los Estados Unidos Mexicanos. (1920).Reglamento de Construcción (D.O.Federación, Ed.)

[16] Gobierno Constitucional de los Estados Unidos Mexicanos. (1942).Reglamento de Construcción (D.O.Federación, Ed.)

[17] Zeevaert-Wiechers A. La torre Latino Americana. Mexico: División de Estudios Superiores de la Facultad de Ingeniería, UNAM. 